\title{
RAPD-SCAR Markers: An Interface Tool for Authentication of Traits
}

\author{
Sameer S. Bhagyawant \\ School of Studies in Biotechnology, Jiwaji University, Gwalior, India \\ Email: sameerbhagyawant@gmail.com
}

Received 26 October 2015; accepted 22 December 2015; published 25 December 2015

Copyright (C) 2016 by author and Scientific Research Publishing Inc.

This work is licensed under the Creative Commons Attribution International License (CC BY).

http://creativecommons.org/licenses/by/4.0/

(c) (i) Open Access

\begin{abstract}
The versatility of the PCR technique is that several kinds of primers can be explored for genome analysis depending on the purpose of study. The easy to access and low cost PCR-based markers include Random Amplified Polymorphic DNA (RAPD). The RAPD markers are easy to develop but lack of reproducibility makes it less reliable and obstacles to their further use in authentication of traits. In addition, other PCR and non PCR based markers like Amplified Fragment Length Polymorphism (AFLP), Simple Sequence Repeat (SSR) and Restriction Fragment Length Polymorphism (RFLP) are also employed in authentication of traits with certain restrictions vis-à-vis use of radioactive materials, high cost and requirement of sequence information etc. Therefore, this problem can be overcome by converting RAPD markers to more robust sequence characterized amplified regions i.e. SCAR markers. SCARs are locus specific, co-dominant in nature and amplified by PCR using specific 15 - 30 bp DNA fragments. For developing SCAR markers, primers are designed from the nucleotide sequences of a cloned RAPD fragments linked to a trait of interest. SCAR markers are easy to develop and reliable tools for DNA fingerprinting. This mini review is an attempt to summarize efficacy of RAPD-SCAR interface in authentication of traits.
\end{abstract}

\section{Keywords}

SCAR Marker, Molecular Marker

\section{Introduction}

A molecular genetic marker is a gene or DNA sequence used to identify different features in species. DNA based markers are categorized into non-PCR-based and PCR-based. Non-PCR-based markers are informative but practical involvement of radioactive isotopes, high cost, absolute requirement of sequence information and sophisticated laboratory set up limits their usage [1] [2]. PCR-based markers have been widely used because of 
their technical simplicity, ease of screening large number of samples in a short period of time and can be carried out in a moderately equipped laboratory. Specific, semi-specific and arbitrary primers can be used in various combinations to target DNA motifs/genes of interest [1].

One of the simplest and most pervasive applications of PCR-based DNA markers in plants is DNA fingerprinting [3]. Seed companies and national registration agencies have an interest in DNA fingerprinting because the technology can be used to protect intellectual property, establish identity and assess purity. For these reasons, DNA fingerprinting has to be an integral part of research organizations. Equally their systematic authentications with fast and reliable methods are very much demanding. SCAR markers have proven their utility in detection of Fusarium oxysporium f. sp. ciceris and cubense [4] [5], selection of hybrid strains of Saccharomyces cerevisiae [6], validation of sex of plants in early stage [7] and identification of powdery mildew resistance genes [8]. The several potential applications that are put together by earlier workers are well summarized in Table 1 . This mini review is an attempt to summarize the available information between 2010-2015; vis-à-vis RAPD-SCAR maker development and its use as an interface tool for authentication of traits in diverse biological systems.

\section{RAPD Markers}

RAPD is a PCR-based technique introduced by Williams et al. [9]. It employs single primers with 10 nucleotides and a GC content of at least 50\%. PCR products are separated on agarose gels and detected by ethidium bromide staining. In this, amplification reactions are carried out under relaxed stringency conditions and no prior knowledge of DNA sequence is required. The basic principles of this technique have been presented by three independent groups in early 1990s, each suggesting different protocols [9]-[11]. Technically, RAPD primer sequences are arbitrarily chosen and the genome is expected to be sampled randomly.

The advantage of RAPD-PCR, as depicted in Table 2, is its technical simplicity paired with independence of any prior DNA sequence information [9] [10]. The low stringency annealing temperatures of $35^{\circ} \mathrm{C}-45^{\circ} \mathrm{C}$ allow primer competition to genome size more closely. Being a dominant marker, its use for population genetics and genome mapping is restricted. Hence a further extension of RAPD to more authenticate SCAR marker is prerequisite for transforming its applicability. Most, but not all, of the RAPD markers inherit in a dominant fashion and are scored as presence/absence polymorphisms [12].

Consistency of RAPD markers is debatable. RAPD technique is sensitive to changes in the reaction conditions. Therefore, there exists a gap between the ability to obtain la linked markers to a gene of interest in a short time and the use of these markers for map based cloning approaches and for routine screening procedures. When sorghum germplasm consisting of 42,000 accessions was analyzed with RAPD markers, the clusters developed were not close to those obtained on the basis of morphological and agronomic data [13]. There exist many examples revealing ambiguous nature of RAPD marker which needs to be authenticated with an interface tools like SCAR markers.

\section{Sequence Characterized Amplified Regions (SCAR)}

In 1993, RAPD-derived molecular marker i.e. SCAR marker was first of all developed by Paran and Michelmore for downy mildew resistance genes in lettuce [13]. They used SCAR markers as a genetic marker for tagging the gene of interest in lettuce from parents of mapping population. SCARs have the advantages over RAPD markers in having additional specificity and reproducibility. SCARs may identify polymorphisms that are less accessible by other techniques. SCAR is also one of the PCR-based monolocus and co-dominant genetic markers can also be useful in physical mapping. SCARs will bridge the gap between the ability to obtain molecular markers linked to genes of interest in a short time and use of these markers in a map-based cloning approac.

Technically, developing a SCAR marker requires the use of two specific primers designed from nucleotide sequence established in cloned RAPD fragment linked to a trait of interest. Once it is developed, large number of samples can be screened at a time thus reduces the time and enhances reliability [15]. Thus, number of reactions required to fingerprint many samples could be reduced to one. SCAR marker separation efficiency is better than that of RAPD markers based on the number of reactions required per sample. In addition, the SCAR marker gels are cleaner and much easier to score assisting computer automation. The only limitation of its development may be the requirement of sophisticated laboratory facilities like sequencing.

SCAR markers have been developed for authentication of traits in various biological systems vis-à-vis Sorghum halepense [16], Oryza sativa [17], Pennisetum glaucum [18], Eucalyptus grandis [19], Pisum sativum [8], 
Table 1. Plant parts used for developing SCAR markers with their application.

\begin{tabular}{|c|c|c|c|c|c|c|}
\hline Plants & Parameter & $\begin{array}{l}\text { Size of } \\
\text { SCAR } \\
\text { marker }\end{array}$ & RAPD primer & SCAR primer & Applications & Links \\
\hline $\begin{array}{c}\text { Saccharomyces } \\
\quad \text { cerevisiae } \\
\text { (Wang et al., 2011) }\end{array}$ & $\begin{array}{l}\text { Bacterial } \\
\text { strain }\end{array}$ & & S1308 (5’-CTGTCTGTG-3’) & $\begin{array}{c}\text { A1 (5'-CTGTCTGTGGGAAATACGAACC-3') } \\
\text { A2 (5'-CTGTCTGTGGACCTAAAACGCT-3') } \\
\text { C3 (5'-GAACGAACTGTCTGTGGTAGTGC-3'), } \\
\text { C4 } \\
\text { (5'-GAACAGAACTGTCTGTGGTAGTGC-3') }\end{array}$ & $\begin{array}{l}\text { To select hybrid } \\
\text { strains of } \\
\text { Saccharomyces } \\
\text { cerevisiae }\end{array}$ & $\begin{array}{l}10.1007 / \mathrm{s} 11274-0 \\
10-0430-7\end{array}$ \\
\hline $\begin{array}{l}\text { Pisum sativum L. } \\
\text { ( Srivastava et al., } \\
\text { 2012) }\end{array}$ & $\begin{array}{l}\text { Leaves, } \\
\text { Stipules }\end{array}$ & 880 bp & OPX 04 (5’-CCGCTACCGA-3’) & $\begin{array}{c}\text { ScOPX } 04_{880} \\
\text { (5'-CCGCTACCGATGTTATGTTTG-3’) } \\
\text { (5'-CCGCTACCGAACTGGTTGGA-3') }\end{array}$ & $\begin{array}{l}\text { SCAR marker } \\
\text { linked to powdery } \\
\text { mildew resistance } \\
\text { gene er1 in pea }\end{array}$ & $\begin{array}{l}10.1007 / \mathrm{s} 10681-0 \\
12-0650-\mathrm{z}\end{array}$ \\
\hline $\begin{array}{l}\text { Liriope platyphylla } \\
\text { \& Ophiopogon } \\
\text { japonicas } \\
\text { (Li and Park, 2012) }\end{array}$ & $\begin{array}{l}\text { Leaves, } \\
\text { Tuber }\end{array}$ & $\begin{array}{l}460 \text { bp } \\
553 \text { bp }\end{array}$ & $\begin{array}{l}\text { OPA-06 F, (5'-GGTCCCTGAC-3') } \\
\text { OPA-06 R, (5'-GGTCCCTGAC-3') }\end{array}$ & $\begin{array}{c}\text { SA12 F } \\
\text { (5'-TCGGCGATAGTGTAGGATATG-3') } \\
\text { SA12 R (5'-TCGGCGATAGAGGTGATACA-3') } \\
\text { SA06 F (5'-GGTCCCTGACTATATCGTGTT-3') } \\
\text { SA06 R } \\
\text { (5'-GGTCCCTGACACATACACATG-3') } \\
\text { SB05 F } \\
\text { (5'-TGCGCCCTTCAAACAAAACAAG-3') } \\
\text { SB05 R (5'-TGCGCCCTTCCCCAGGTAAC-3') }\end{array}$ & $\begin{array}{l}\text { Identification of } \\
\text { closely related } \\
\text { medicinal plant } \\
\text { species }\end{array}$ & $\begin{array}{l}10.1186 / 2193-18 \\
01-2-501\end{array}$ \\
\hline $\begin{array}{l}\text { Hippophae } \\
\text { rhamnoides L. } \\
\text { (Korekar et al., } \\
\text { 2012) }\end{array}$ & Leaves & 470 bp & $\begin{array}{l}\text { OPA-04 (5'-AATCGGGCTG-3' } \\
\text { OPT06 (5'-CAAGGGCAGA-3') }\end{array}$ & $\begin{array}{l}\text { OPA-04(FS)F(5'-TATGAGCTCTCGACTGACA } \\
\text { GCCA-3') } \\
\text { OPA-04(FS)R(5'-CTDTTGTCCGAGATGACGC } \\
\text { GT-3') }\end{array}$ & $\begin{array}{l}\text { To determine the } \\
\text { sex of } \\
\text { seabuckthorn } \\
\text { plants in early } \\
\text { stage }\end{array}$ & $\begin{array}{l}10.1007 / \mathrm{s} 10529-0 \\
12-0852-4\end{array}$ \\
\hline $\begin{array}{l}\text { Fusarium } \\
\text { oxysporium f. sp. } \\
\text { ciceris } \\
\text { (Durai et al., 2012) }\end{array}$ & Mycelia & & $\begin{array}{l}\text { OPA } 11 \text { (5'-CAATCGCCGT-3') } \\
\text { OPA } 7 \text { (5'-GAAACGGGTG-3') }\end{array}$ & $\begin{array}{c}\text { SC-FOC1 } \\
\text { F-(5’-CCTCGCCAGCCTTGTACTTGCG-3’) } \\
\text { SC-FOC1 } \\
\text { R-(5'-CGGTACCGGATGGCCCTGCAA-3’) } \\
\text { SC-FOC2 } \\
\text { F-(5'-ATGGCTCAGTGAGGCGTCCGGA-3’) } \\
\text { SC-FOC2 } \\
\text { R-(5'-GTGTGGGGGATAGAGCATTG-3’) }\end{array}$ & $\begin{array}{l}\text { Detection of } \\
\text { Fusarium } \\
\text { oxysporium f. sp. } \\
\text { causing wilt in } \\
\text { chickpea }\end{array}$ & $\begin{array}{c}10.1007 / \mathrm{s} 12223-0 \\
12-0118-5\end{array}$ \\
\hline $\begin{array}{l}\text { Rhizoctonia solani } \\
\text { (Ganeshamoorthi } \\
\text { and Dubey, 2013) }\end{array}$ & Root & 285 bp & OPA 11 (5'-CAATCGCCGT-3’) & $\begin{array}{l}\text { SCAR-GSF (5’-GTGGA ACCAA GCATA } \\
\text { ACACT GA-3') } \\
\text { SCAR-GS R (5’-AGTTT CAACA ACGGA } \\
\text { TCTTT GG-3’) }\end{array}$ & $\begin{array}{l}\text { Detection of wet } \\
\text { root rot pathogen } \\
\text { in chickpea }\end{array}$ & $\begin{array}{l}\text { 10.5897/AJB201 } \\
3.12439\end{array}$ \\
\hline $\begin{array}{l}\text { Oryza sativa L. } \\
\text { (Semsang et al., } \\
\text { 2013) }\end{array}$ & Seed & 218 bp & OPO07 (5'-CAGCACTGAC-3') & $\begin{array}{c}\text { BO07F1(5'-TGTCTACGTTGGCTTCGCCATCA } \\
\text { CCG-3') } \\
\text { BO07R1(5'-ATGCTAACCATG } \\
\text { TATTAGTCATG-3') }\end{array}$ & $\begin{array}{l}\text { Discrimination of } \\
\text { Thai jasmine rice } \\
\text { mutants }\end{array}$ & $\begin{array}{l}\text { 10.4236/ajps. } 201 \\
3.49218\end{array}$ \\
\hline $\begin{array}{c}\text { Sorghum } \\
\text { halepense L. } \\
\text { (Zhang et al., 2013) }\end{array}$ & Seeds & & $\begin{array}{c}\text { CP3 } \\
\text { (5’-GTGTTGACGAGATTTCTGTT-3') } \\
\text { CP4 } \\
\text { (5'-GGGTTGCTAACTCAATGGTA-3') }\end{array}$ & $\begin{array}{l}\text { SH1 (5'-AGATTGAGTCTCAGGTGC-3') } \\
\text { SH2 (5’-GAGTCTCAGGGTATGATCT-3') }\end{array}$ & $\begin{array}{l}\text { To distinguish } S \text {. } \\
\text { halepense and its } \\
\text { relatives }\end{array}$ & $\begin{array}{l}\frac{\text { http://www.notula }}{\text { ebotani- }} \\
\underline{\text { cae.ro/index.php/ }} \\
\underline{\text { nbha/view/9001 }}\end{array}$ \\
\hline $\begin{array}{l}\text { Idesia polycarpa } \\
\quad \text { Maxim. } \\
\text { (Wang et al., 2014) }\end{array}$ & Leaves & 200 bp & $\begin{array}{c}\text { me14 } \\
\text { (5’-TGAGTCCAAACCGGAGT-3') } \\
\text { em18 } \\
\text { (5’-GACTGCGTACGAATTTCA-3’) }\end{array}$ & $\begin{array}{l}\text { TZS1 (5’-TGAGTCCAAA CCGGAGTAAA-3') } \\
\text { TZS2 (5'-CAATTCAGGG ATTTAACCAC-3') }\end{array}$ & $\begin{array}{l}\text { Early sexual } \\
\text { identification in } \\
\text { Idesia } \\
\text { polycarpa }\end{array}$ & $\begin{array}{l}\text { 10.4238/2015.Mar } \\
\text { ch. } 20.11\end{array}$ \\
\hline $\begin{array}{l}\text { Rosa indica } \\
\text { (Bashir et al., 2014) }\end{array}$ & Leaves & 391 bp & GLB-15 (5’-GGAGGGTGTT-3’) & $\begin{array}{c}\text { Forward: } \\
\text { (5’-CTAGGAATTAGGGTGTCTAGG-3') } \\
\text { Reverse: (5'-CTGAGGTCTTGAGTCTCAGG-3') }\end{array}$ & $\begin{array}{l}\text { Identification and } \\
\text { authentication of } \\
\text { Rosa species }\end{array}$ & $\begin{array}{l}\text { 10.4238/2014.Ma } \\
\mathrm{y} .30 .8\end{array}$ \\
\hline $\begin{array}{l}\text { Lactobacillus } \\
\text { plantarum } \\
\text { (Liu et al., 2015) }\end{array}$ & Strains & 680 bp & S116 ( 5’-TCTCAGCTGG-3’) & $\begin{array}{l}\text { SA1 (5'-TCTCAGCTGGCACAAGGTGTTG-3') } \\
\text { SA2 (5'-TCTCAGCTGGCATTGGATTTTC-3') }\end{array}$ & $\begin{array}{l}\text { To determine acid } \\
\text { resistance related } \\
\text { gene in } \\
\text { Lactobacillus } \\
\text { plantarum }\end{array}$ & $\begin{array}{l}10.1007 / \mathrm{s} 00792-0 \\
14-0721-2\end{array}$ \\
\hline
\end{tabular}




\begin{tabular}{|c|c|c|c|c|c|}
\hline \multicolumn{6}{|l|}{ Continued } \\
\hline $\begin{array}{l}\text { Litchi chinensis } \\
\quad \text { Sonn. } \\
\text { (Chang et al., 2015) }\end{array}$ & Leaves & $\begin{array}{l}250 \mathrm{bp} \\
550 \mathrm{bp} \\
\text { and } \\
150 \mathrm{bp} \\
400 \mathrm{bp}\end{array}$ & $\begin{array}{l}\text { SBC-I10 } \\
\text { SBC-A12 } \\
\text { SBC-A16 }\end{array}$ & $\begin{array}{l}\text { L7-16L (5'-AGCTGAGGGTGCATTACGAT-3') } \\
\text { L7-16R ( 5'-TGGCAAAGTCTGGTCTCAAA-3') } \\
\text { L9-6L (5'-TATCAAAAACGCAGCCGTTA-3') } \\
\text { L9-6R (5'-ACAGGACCCTTTCCAGACCT-3') } \\
\text { L11-26L (5'-TCCTTCAGGGATTCGTTTTG-3') } \\
\text { L11-26R (5'-GATCCCTACGACCATCTGGA-3') }\end{array}$ & $\begin{array}{c}\text { Identification of } \\
\text { Litchi chinensis } \\
\text { sonn. } \text { species }\end{array}$ \\
\hline $\begin{array}{l}\text { Eucalyptus grandis } \\
\text { (Laia et al., 2015) }\end{array}$ & Leaves & 800 bp & AT9 R (5’-ACGCTAACGG-3’) & $\begin{array}{c}\text { AT99151L } \\
\text { (5-‘CCGTTAGCGTGAGTAGATGTAGAG-3’) } \\
\text { AT9915914R } \\
\text { (5’-CGTTAGCGTCATCAGTAGGTCA-3’) }\end{array}$ & $\begin{array}{l}\text { Marker-assisted } \\
\text { selection of } E \text {. } \\
\text { grandis trees } \\
\text { 10.5897/AJAR20 } \\
\text { resistance to } P \text {. } \\
\text { psidii Winter. }\end{array}$ \\
\hline $\begin{array}{l}\text { Fusarium oxysprum } \\
\text { f. sp. cubenes in } \\
\quad \text { banana } \\
\text { (Cunha et al., 2015) }\end{array}$ & $\begin{array}{l}\text { Bacterial } \\
\text { strain }\end{array}$ & 1700 bp & OPP-12 (5’-AAGGGCGAGT-3’) & $\begin{array}{l}\text { SuscPD-F (5'-GAACCAGAGCCAGGGCATAG-3') } \\
\text { SuscPD-R (5'-TCTATGCGCCTACCCTCCTT-3') }\end{array}$ & $\begin{array}{lc}\text { To discriminate } & \\
\text { resistant and } & 10.1016 / \text { j.scienta. } \\
\text { susceptible } & 2015.04 .038 \\
\text { genotypes to } & \\
\text { Foc infection } & \end{array}$ \\
\hline $\begin{array}{l}\text { T. harzanium } \\
\text { T. viride } \\
\text { (Parmar et al., } \\
\text { 2015) }\end{array}$ & Mycelia & $\begin{array}{l}220 \text { bp } \\
900 \text { bp }\end{array}$ & $\begin{array}{l}\text { OPA-16 (5'-AGCCAGCGAA-3') } \\
\text { OPC-05 (5'-GATGACCGCC-3') }\end{array}$ & $\begin{array}{c}\text { HAR220FP5 (5'-CTTTTGGTTTGACACGGTTCT-3') } \\
\text { HAR220RP5 } \\
\text { (5'-AAGCTTTGAAGTTGCGAGGA-3') } \\
\text { VIRI900FP7 } \\
\text { (5'-TACGCTCCAGGCTACCACTT-3') VIRI900RP7 } \\
\text { (5'-GAGATGAGCTCCTTGCTGCT-3') }\end{array}$ & $\begin{array}{cc}\text { To distinguish } & \text { 10.12691/ajmr-3- } \\
\text { Trichoderma } & 1-7 \\
\text { species } & \end{array}$ \\
\hline $\begin{array}{l}\text { Fusarium } \\
\text { oxysporum f. sp. } \\
\text { Radicis-lycopersici } \\
\text { (Mutlu et al., 2015) }\end{array}$ & leaves & 1000 bp & & $\begin{array}{c}\text { SCAR200 } \\
\text { F(5'-TCGGTCCAAATTCACTTCAA-3') } \\
\text { R(5'-ACTCCTCCACTTGCATACCC-3') } \\
\text { SCARFr } \\
\text { F(5'-CACATTCATCATCTGTTTTTAGTCTATTC-3') } \\
\text { R(5'-CACAATCGTTGGCCATTGAATGAAGAAC-3') }\end{array}$ & $\begin{array}{l}\text { To study linkage } \\
\quad \text { of } 10.1007 / \mathrm{s} 00122-0 \\
\text { Fr1 gene in } \\
\text { tomato }\end{array}$ \\
\hline
\end{tabular}

Table 2. Comparison of various features of molecular markers.

\begin{tabular}{cccc}
\hline Feature & ISSR & RAPD & SCAR \\
\hline Plant material required & Little & Little & Little \\
Information generated & High and specific & High and nonspecific & Low and specific \\
Time required for detection & Short & Short & Short \\
Loci (single/multiple) & Multiple/single & Multiple & Single \\
Principle & DNA amplification & DNA amplification & DNA amplification \\
PCR based markers & Yes & Yes & Yes \\
Reproducibility & Moderate & Moderate & High \\
Part of genome & Whole genome & Whole genome & Part of genome \\
Use and development & Difficult & Moderate & Low \\
Reliability & High & Low & High \\
Use of radioactivity & No & Yes/No & No \\
Development time & Long & Short & Short
\end{tabular}

R. solanacearum [20], R. solani [21], F. oxysporum f. sp. radicis-lycopersici [22], Saccharomyces cerevisiae [6] and Trichoderma harzanium Trichoderma viride [23] etc. 


\section{Development of SCAR Markers}

The fragment polymorphisms produced by RAPD-PCR amplifications are not always reproducible [2]. This limitation can be overcome by converting RAPDs into sequence-characterized amplified region i.e. SCAR. The SCAR marker has proven to be more reproducible for the authentication and identification of genotypes [24] [14]. SCAR markers may contain high-copy number and dispersed genomic sequences within the amplified region. Thus, they are valuable in large scale and locus-specific applications such as marker-assisted screening and map-based gene cloning. The other PCR-based/non-PCR-based methods like AFLP, SSR and ISSR have reproducible amplifications patterns than RAPD markers. But development of SCAR markers from theses markers are laborious and time consuming. A SCAR marker, generated from polymorphic regions that differ in size between species, permits sample authentication based on SCAR size shifts. Thus SCAR marker has came out as a best marker technology for authentication of crop species [15].

\section{Procedure}

To develop RAPD-SCAR marker, purification of PCR fragments followed by designing of SCAR primer is practiced [14] [15]. Briefly, a polymorphic band of interest is identified, selected and eluted from agarose gel. The nucleotide sequence of the eluted DNA fragment is determined. The nucleotide sequence of the polymorphic DNA band is thereafter analysed for sequence uniqueness by comparing with the known DNA sequences available at NCBI database, using BLAST. Finally, the nucleotide sequence of the polymorphic DNA band is used to synthesize specific SCAR primers (Figure 1).

Another approach includes indirect sequencing of RAPD amplicons. Shortly, polymorphic DNA fragments of interest is cloned in a suitable vector and transformation is done using high efficiency competent cells of DH-5 $\alpha$ strain of E. coli. Further, clones are selected for plasmid DNA isolation. The same size fragments corresponding to the RAPD markers can be recovered from restriction enzyme digetion and the ends of the cloned fragments are sequenced. Specific SCAR markers are designed including the sequence of the original 10-mer primer with supplementary 11 - 15 bases 3 to the 10-mer [14] [15]. The newly designed SCAR primers are tested using PCR for authentication of a particular trait/genotyping (Figure 2).

\section{Applications of SCAR Marker}

The utility of SCAR markers in authentication of medical herbs are well reviewed [15]. In this mini review, ap-

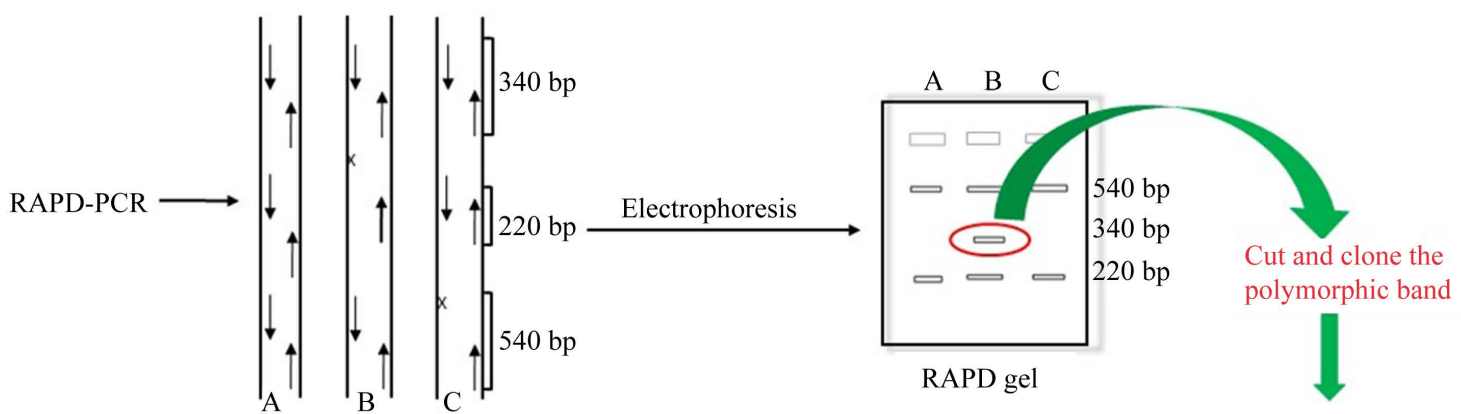

Sequence the amplicon, BLAST and design trait specific primers

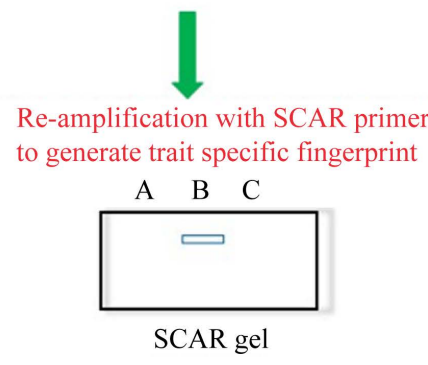

Figure 1. SCAR marker development (direct method) [25]. 

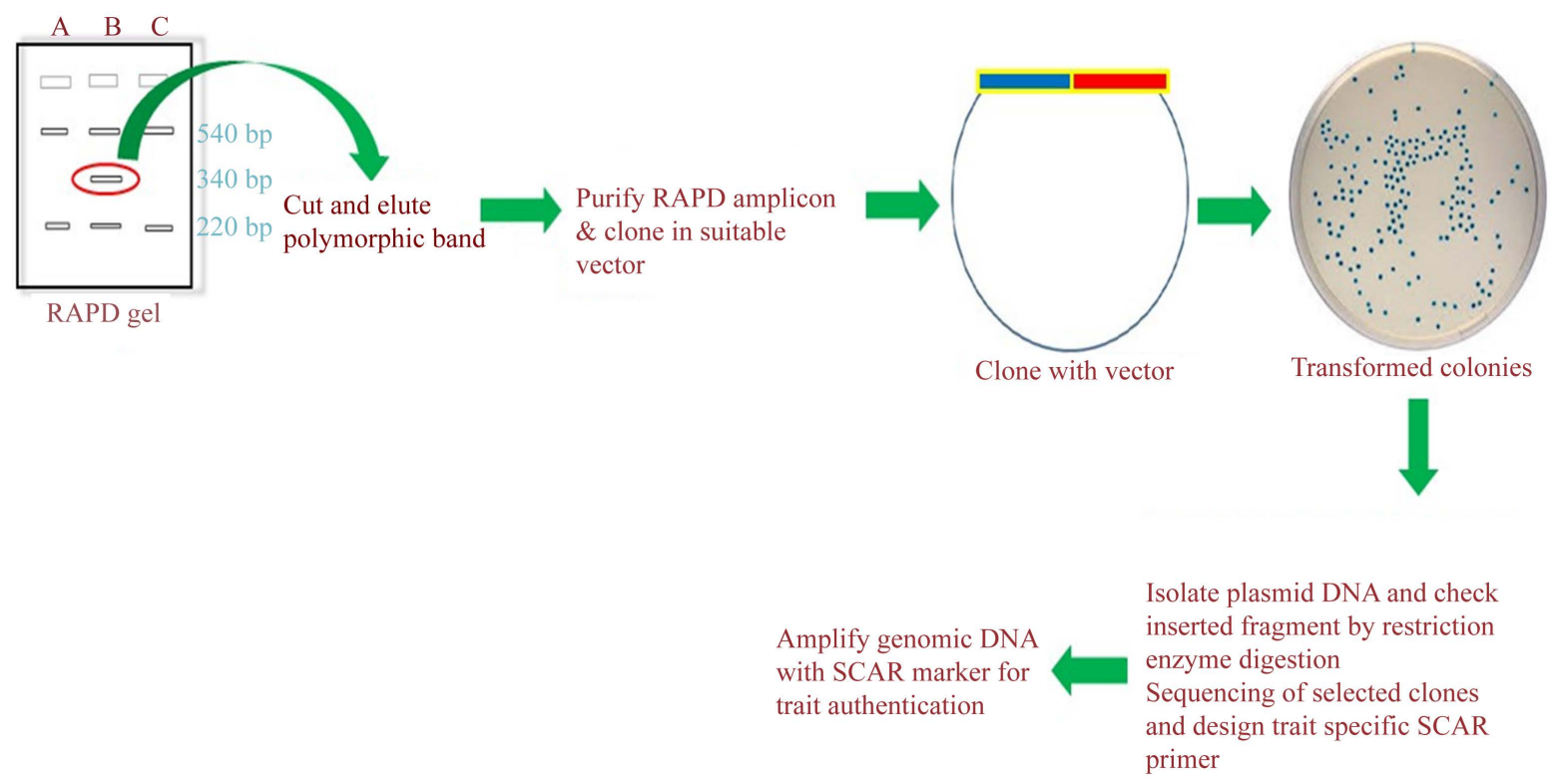

Figure 2. SCAR marker development (in-direct method) [15].

plications of SCAR marker as a interface that are developed after 2010 are reported. SCAR markers are locus specific and therefore, can easily be identified. The concept of generating locus-specific SCARs from anonymous PCR fragments is not restricted to RAPDs but can also be applied to other multilocus marker techniques such as AFLPs. Fragments of interest are physically isolated from a multilocus banding pattern, and either re-amplified or cloned prior to sequencing (Figure 3).

RAPD-SCAR can be applied in industrial breeding instead of auxotrophic markers. The strains of Saccharomyces cerevisiae, the most useful species of yeast, are instrumental to winemaking, baking, and brewing since ancient times. Protoplast fusion has the potential to generate improved hybrids possessing novel combinations of parent characteristics [6]. Yeast breeding by protoplast fusion however, has a limited practical applications that can be successfully employed for screening of hybrid strains [26]. Wang et al. overcome this drawback. The parent Saccharomyces cerevisiae strains Z8 and Z9, showing high ethanol production, were electrofused and hybrids were screened by PCR using SCAR markers. Hence utility of SCAR markers can be employed in selecting strains from protoplast fusion in industrial breeding [6].

Powdery mildew is one of the major constraints in pea production worldwide causing severe seed losses. The resistance is governed by a single recessive gene er1 in majority of the resistant cultivars, but er2 and er3 have also been reported. Srivastava et al. developed a coupling-phase SCAR marker linked to the powdery mildew resistance gene "er1" gene in pea (Pisum sativum L.) They demonstrated successfully that the RAPD-SCAR marker systems could be used for pyramiding genes against powdery mildew pathogen [8].

RAPD-SCAR marker also proved their potency in discriminating species of therapeutically important medicinal plants. Such molecular maker is becoming increasingly popular tools of preferred choice for raw drug authentication and management of herbal drugs [27]. The actinorhizal plant seabuckthorn (Hippophae rhamnoides L., Elaeagnaceae) is a wind pollinated dioecious crop. For the first time, sex-specific SCAR markers were developed in seabuckthorn. The studies of Korekar et al. [7] reported for the first time two robust sex-linked SCAR markers, namely HrX1 and HrX2. The RAPD-SCAR patterns authenticated large sets of 120 female plants and rejected 100 male plants. Thus, such a robust SCAR maker developed in seabuckthorn, may provide early sex information and enhance its production for commercial and pharmaceutical exploitations.

Dimocarpus longan, is an edible fruit and source of traditional medicine, mostly grown in the Southern China. D. longan fruits have many medicinal properties like enhancing memory, promoting blood metabolism, relieving insomnia, and preventing amnesia. Yang et al. [28] developed a cloning based RAPD-SCAR marker and validated its usefulness in diagnosing the specific variety authentication, particularly for distinguishing $D$. longan from $D$. confinis. Literature perusal suggests that few studies have also carried out in 2014. Bashir et al. [29] developed a SCAR marker for identification and authentication of Rosa species. A polymorphic RAPD fragment 


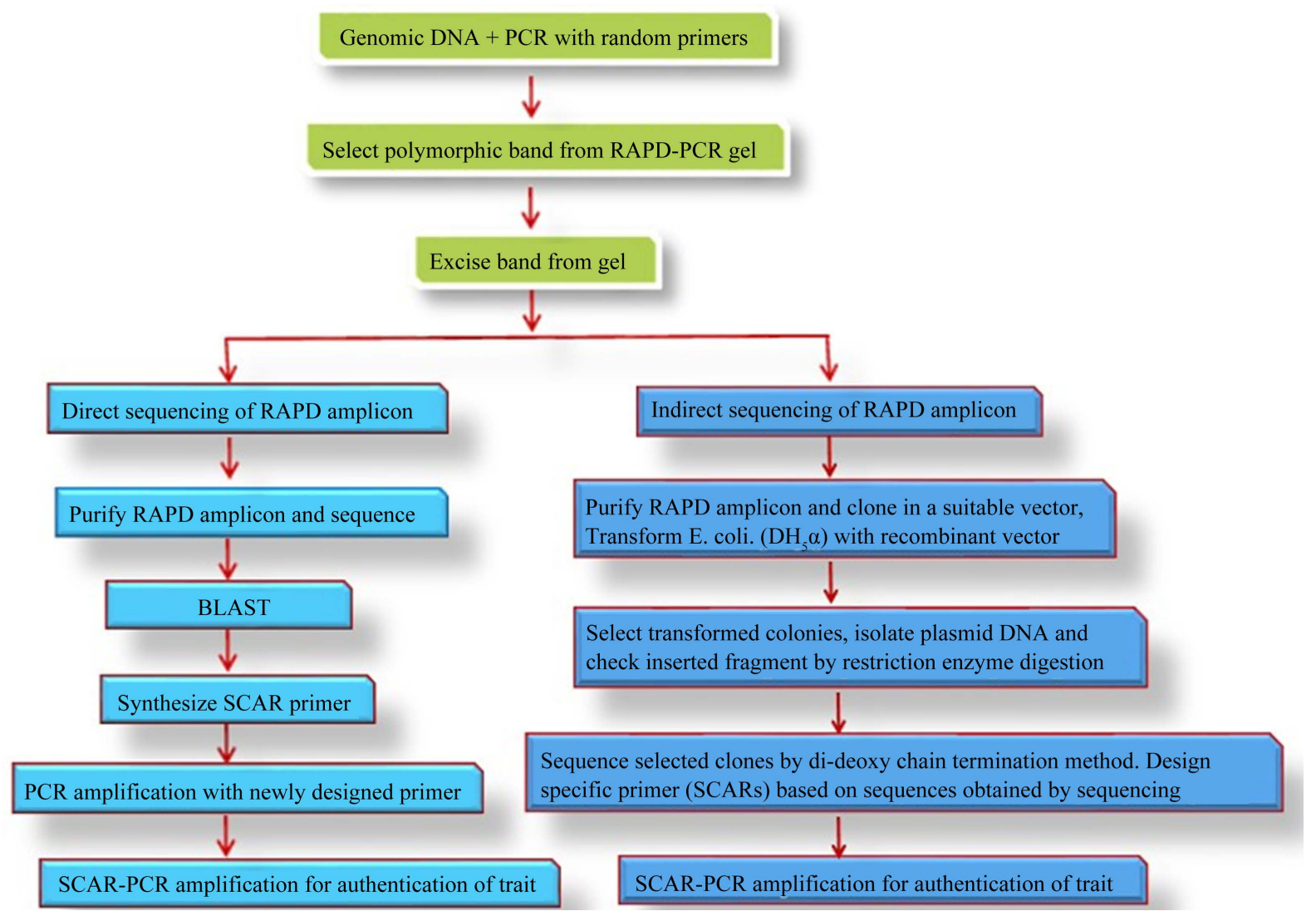

Figure 3. Schematic representation of RAPD-SCAR marker development.

of 391 bp was detected in $R$. bourboniana, which was cloned, purified, sequenced, and used to design a pair of species specific SCAR markers having forward and reverse orientations.

Combining RAPD and SCAR markers provides a simple and reliable tool for the genetic characterization of plant species. Litchi (Litchi chinensis Sonn., L. chinensis), belongs to the family Sapindaceae. It is mostly cultivated in Southeast Asia. Litchi is an edible fruit having many medicinal properties. The numerous litchi cutivars grown across the globe creates confusion regarding their naming and identification. Cheng et al. [30] took a note of this and developed a SCAR marker for the authentication of Litchi species by improved RAPD-SCAR amplification.

The wine industry needs various single-factor or multiple-factor tests to select and evaluate the potential strains. The traditional methods are limited due to its inefficiency and inaccuracy [29]. Wen-Liu et al. [31] developed a SCAR marker for acid resistance-related gene in Lactobacillus plantarum. The results of their studies enabled them to screen desirable malolactic fermentation strains.

The banana is an edible fruit, produced by several kinds of large herbaceous flowering plants in the genus Musa [32]. Panama disease or Fusarium wilt of banana, is caused by Fusarium oxysporum sp. cubense. This fungus infects cultivars causing plant death. Developing resistant/tolerant cultivars is expensive and time consuming and may take years to develop. Molecular techniques offers a potential means to screen our cultivars in a specified field at any stage of its developments. In this context, Cunha et al. [5] have developed a RAPD-SCAR markers as a tool to discriminate resistant and susceptible genotypes of Foc infected banana plants. This diagnostic application of SCAR marker helps the plant breeders to eliminate Foc-susceptible genotypes with a high degree of probability, leaving only the resistant plants for further evaluation.

\section{Future Applications}

The high specificity of SCAR markers can become an important interface tool of DNA fingerprinting. Diagnosis of cultivars selection of hybrid strains of industrial importance, sex determination in plants can be effectively 
done at an early stage to reduce the time, field evaluation and labor cost. The reliability of SCAR markers appears to be the best choice available for DNA fingerprinting vis-à-vis authentication, and trait specific characterization. More number of SCAR markers needs to develop/widen in various biological systems for discrimination of traits of importance.

\section{References}

[1] Mullis, K.B., Ferre, F. and Gibbs, R.A., Eds. (1994) The Polymerase Chain Reaction. Birkhauser, Basel.

[2] Saiki, R.K., Gelfand, D.H., Stoffel, S., Scharf, S.J., Higuchi, R., Horn, G.T., Mullis, K.B. and Erlich, H.A. (1988) Primer Directed Enzymatic Amplification of DNA with a Thermostable DNA Polymerase. Science, 239, 487-491. http://dx.doi.org/10.1126/science.2448875

[3] Soller, M. and Beckmann, J.S. (1983) Genetic Polymorphism in Varietal Identification and Genetic Improvement. Theoretical and Applied Genetics, 67, 25-33. http://dx.doi.org/10.1007/BF00303917

[4] Durai, M., Dubey, S.C. and Triphathi, A. (2012) Genetic Diversity Analysis and Development of SCAR Marker for Detection of Indian Populations of Fusarium oxysporum f. sp. ciceris Causing Chickpea Wilt. Folia Microbiology, 57, 229-235. http://dx.doi.org/10.1007/s12223-012-0118-5

[5] Cunha, C.M.S., Hinz, R.H., Pereira, A. and Tcacenco, F.A. (2015) A SCAR Marker for Identifying Susceptibility to Fusarium oxysporum f. sp. Cunense in Banana. Scientia Horticulturae, 191, 108-112. http://dx.doi.org/10.1016/j.scienta.2015.04.038

[6] Wang, P.M., Wu, X.C., Chi, X.Q., Li, Y.D., Zheng, D.Q., Ding, R. and Min, H. (2011) Development and Application of RAPD-SCAR Markers to Identify Intra-Species Hybrids of Industrial Saccharomyces cerevisiae. World Journal of Microbiology Biotechnology, 27, 185-188. http://dx.doi.org/10.1007/s11274-010-0430-7

[7] Korekar, G., Sharma, R.K., Kumar, R., Meenu, Bisht, C., Srivastava, R.B., Ahuja, P.S. and Stobdan, T. (2012) Identification and Validation of Sex-Linked SCAR Markers in Dioecious Hippophae rhamnoides L. (Elaeagnaceae). Biotechnology Letter, 34, 973-978. http://dx.doi.org/10.1007/s10529-012-0852-4

[8] Srivastava, R.K., Mishra, S.K., Singh, A.K. and Mohapatra, T. (2012) Development of a Coupling-Phase SCAR Marker Linked to the Powdery Mildew Resistance Gene “er1” in Pea (Pisum sativum L.). Euphytica, 186, 855-866. http://dx.doi.org/10.1007/s10681-012-0650-z

[9] Williams, J.G.K., Kubelik, A.R., Livak, K.J., Rafalski, J.A. and Tingey, S.V. (1990) DNA Polymorphism Amplified by Arbitrary Primers Are Useful as Genetic Markers. Nucleic Acids Research, 18, 6531-6535. http://dx.doi.org/10.1093/nar/18.22.6531

[10] Welsh, J. and McClelland, M. (1990) Fingerprinting Genomes Using PCR with Arbitrary Primers. Nucleic Acids Research, 18, 7213-7218. http://dx.doi.org/10.1093/nar/18.24.7213

[11] Caetano-Anolles, G., Bassam, B.J. and Gresshoff, P.M. (1991) High Resolution DNA Amplification Fingerprinting Using Very Short Arbitrary Oligonucleotide Primers. Bio/Technology, 9, 553-557. http://dx.doi.org/10.1038/nbt0691-553

[12] Wang, S., Yang, W. and Shen, H. (2011) Genetic Diversity in Apium graveolens and Related Species Revealed by SRAP and SSR Markers. Scientia Horticulturae, 129, 1-8. http://dx.doi.org/10.1016/j.scienta.2011.03.020

[13] Dahlberg, J.A., Zhang, X., Hart, G.E. and Mullet, J.E. (2002) Comparative Assessment of Variation among Sorghum Germplasm Accessions Using Seed Morphology and RAPD Measurements. Crop Science, 42, 291-296. http://dx.doi.org/10.2135/cropsci2002.0291

[14] Paran, I. and Michelmore, R.W. (1993) Development of Reliable PCR-Based Markers Linked to Downy Mildew Resistance Genes in Lettuce. Theoretical and Applied Genetics, 85, 985-993. http://dx.doi.org/10.1007/BF00215038

[15] Kiran, U., Khan, S., Mirza, K.J., Ram, M. and Abdin, M.Z. (2010) Scar Markers: A Potential Tool for Authentication of Herbal drugs. Fitoterapia, 81, 969-976. http://dx.doi.org/10.1016/j.fitote.2010.08.002

[16] Zhang, W., Liping, Y., Shasha, W.E.I., Deng, Z., Jianping, Y.I., Renqi, W.U. and Chen, Q. (2013) RAPD Marker Conversion into a SCAR Marker for Rapid Identification of Johnsongrass (Sorghum halepense (L.) Pers.). Notulae Botanicae Horti Agrobotanici Cluj-Napoca, 41, 306-312.

[17] Semsang, N., Chundet, R. and Phanchisri, B. (2013) Development of a SCAR Marker for Discrimination of a Thai Jasmine Rice (Oryza sativa L. cv. KDML105) Mutant, BKOS6, and Associated with Purple Color Trait in Thai Jasmine Rice-Related Varieties. American Journal of Plant Sciences, 4, 1774-1783. http://dx.doi.org/10.4236/ajps.2013.49218

[18] Jogaiah, S., Sharathchandra, R.G., Raj, N., Vedamurthy, A.B. and Shetty, H.S. (2014) Development of SCAR Marker Associated with Downy Mildew Disease Resistance in Pearl Millet (Pennisetum glaucum L.). Molecular Biology Report, 41, 7815-7824. http://dx.doi.org/10.1007/s11033-014-3675-7 
[19] Laia, M.L., Alfenas, A.C., Brommonschenkel, S.H., et al. (2015) Identification of a Sequence Characterized Amplified Region (SCAR) Marker Linked to the Puccinia psidii Resistance Gene 1 (Ppr1) in Eucalyptus grandis. African Journal of Microbiology Research, 10, 1957-1964.

[20] Truong, H.T.H., Kim, S., Tran, H.N., Nguyen, T.T.T., Nguyen, L.T. and Hoang, T.K. (2015) Development of SCAR Marker Linked to Bacterial Wilt (Ralstonia solanacerum) Resistance in Tomato Line Hawaii 7996 Using BulkedSegregant Analysis. Horticulture Environment and Biotechnology, 56, 506-515. http://dx.doi.org/10.1007/s13580-015-1050-9

[21] Ganeshamoorthi, P. and Dubey, S.C. (2013) Phylogeny Analysis of Indian Strains of Rhizoctonia solani Isolated from Chickpea and Development of Sequence Characterized Amplified Region (SCAR) Marker for Detection of the Pathogen. African Journal of Microbiology Research, 7, 5516-5525.

[22] Mutlu, N., Demirelli, A., Ilbi, H. and Ikten C. (2015) Development of Co-Dominant SCAR Markers Linked to Resistant Gene against the Fusarium oxysporum f. sp. radicis-lycopersici. Theoretical and Applied Genetics, 128, 17911798.

[23] Parmar, H.J., Hassan, M.M., Bodar, N.P., Lakhani, H.N., Umrania, V.V. and Golakiya, B.A. (2015) Development of SCAR Marker for Specific Detection of Trichoderma harzanium and Trichoderma viride. American Journal of Microbiology Research, 3, 45-49.

[24] Li, H.B., Wu, X.Q., Peng, H.Z., Fu, L.Z., Wei, H.L., Wu, Q.Q., Jin, Q.Y. and Li, N. (2008) New Available SCAR Markers: Potentially Useful in Distinguishing a Commercial Strain of the Superior Type from Other's Trains of Lentinula edodes in China. Applied Microbiology and Biotechnology, 81, 303-309. http://dx.doi.org/10.1007/s00253-008-1671-3

[25] Weising, K., Nybom, H., Wolff, K. and Kahl, G. (2005) DNA Fingerprinting in Plants. CRC Press, Taylor \& Francis group, Boca Raton. http://dx.doi.org/10.1201/9781420040043

[26] Urano, F., Wang, X., Bertolotti, A., Zhang, Y., Chung, P., Harding, H.P., et al. (2000) Coupling of Stress in the ER to Activation of JNK Protein Kinases by Transmem-Brane Protein Kinase IRE1. Science, 287, 664-666. http://dx.doi.org/10.1126/science.287.5453.664

[27] Li, G. and Park, Y-J. (2012) Scar Markers for Discriminating Species of Two Genera of Medicinal Plants, Liriope and Ophiopogon. Genetics and Molecular Research, 11, 2987-2995. http://dx.doi.org/10.4238/2012.May.18.14

[28] Yang, L., Fu, S., Khan, M.A., Zeng, W. and Fu, J. (2013) Molecular Cloning and Development of RAPD-SCAR Markers for Dimocarpus longan Variety Authentication. Springerplus, 2, 501. http://dx.doi.org/10.1186/2193-1801-2-501

[29] Bashir, K.M.I., Awan, F.S., Khan, I.A., Khan, A.I. and Usman, M. (2014) Identification and Authentication of Rosa Species through Development of Species-Specific SCAR Marker(s). Genetics and Molecular Research, 13, 4130-4139. http://dx.doi.org/10.4238/2014.May.30.8

[30] Cheng, J., Long, Y., Khan, M.A., Wei, C., Fu, S. and Fu, J. (2015) Development and Significance of RAPD-SCAR Markers for the Identification of Litchi chinensis Sonn. by Improved RAPD Amplification and Molecular Cloning. Electronic Journal of Biotechnology, 18, 35-39. http://dx.doi.org/10.1016/j.ejbt.2014.11.004

[31] Liu, S.W., Li, K., Yang, S.F. and He, L. (2015) Development of a SCAR (Sequence-Characterized Amplified Region) Marker for Acid Resistance-Related Gene in Lactobacillus plantarum. Extremophiles, 19, 355-361. http://dx.doi.org/10.1007/s00792-014-0721-2

[32] Morton, J.F. (1987) Banana. In: Morton, J.F., Ed., Fruits of Warm Climates, Florida Flair Books, Miami. 